GRASAS Y ACEITES 72 (3)

July-September 2021, e423

ISSN-L: 0017-3495

https://doi.org/10.3989/gya.0554201

\title{
Kinetic modeling of oxidation parameters and activities of lipase-lipoxygenase in wheat germ oil
}

\author{
ㄷ․ Erim Köse ${ }^{凶}$ \\ Van Yüzüncü Y1l University, Faculty of Engineering, Department of Food Engineering, Van-Turkey \\ ${ }^{\square}$ Corresponding author: yagmurerim@yyu.edu.tr
}

Submitted: 07 May 2020; Accepted: 20 July 2020; Published online:24 September 2021

SUMMARY: This study aimed to investigate the oxidation profile of wheat germ oil extracted from raw germ during the stabilization with microwave (MW) treatment, and the kinetics of the oxidation parameters (free fatty acids (FFA), peroxide value (PV), thiobarbituric acid (TBA), $\alpha$-tocopherol, lipase (LA) and lipoxygenase (LOX) enzymes activities) under different storage conditions. For stabilizing raw germ, the MW was treated at $700 \mathrm{~W}$ for three minutes. The oxidation parameters for the kinetic modeling were analyzed at different storage times $(0,15,30,45,60,75,90$, and 105 . days $)$ and storage temperatures $\left(-18,0,4\right.$, and $\left.25^{\circ} \mathrm{C}\right)$. The parameters were mathematically modelled and the PV and LA fitted well to the zero-order kinetic model, while FFA with $\alpha$-tocopherol and TBA followed the first and second-order kinetics, respectively. The kinetic constant $(\mathrm{k})$ was described by an Arrhenius equation and the activation energy ranged from 5.72 to $18.5 \mathrm{~kJ} / \mathrm{mol}$ for the stabilized germ.

KEYWORDS: Activation energy; Kinetic parameters; Lipase enzyme; Oxidative stability

RESUMEN: Modelo cinético de los parámetros de oxidación y actividades de la lipasa-lipoxigenasa en aceite de germen de trigo. Este estudio tuvo como objetivo investigar el perfil de la oxidación del aceite crudo extraído del germen de trigo durante tratamientos de estabilización con microondas (MW), y la cinética de los parámetros de oxidación (ácidos grasos libres (FFA), índice de peróxido (PV), ácido tiobarbitúrico (TBA), actividades de enzimas $\alpha$-tocoferol, lipasa (LA) y lipoxigenasa (LOX), en diferentes condiciones de almacenamiento. Para estabilizar el germen crudo en MW, se trató a $700 \mathrm{~W}$ durante tres minutos. Los parámetros de oxidación para el modelo cinético se analizaron a diferentes tiempos de almacenamiento $(0,15,30,45,60,75,90$ y 105 días $)$ y temperaturas de almacenamiento $\left(-18,0,4\right.$ y $\left.25^{\circ} \mathrm{C}\right)$. Los parámetros fueron tratados matemáticamente y el PV y LA se ajustaron bien al modelo cinético de orden cero, mientras que FFA con $\alpha$-tocoferol y TBA siguieron una cinética de primer y segundo orden, respectivamente. La constante cinética (k) se describió mediante una ecuación de Arrhenius y la energía de activación varió de 5,72 a 18,5 kJ/mol para los gérmenes estabilizados.

PALABRAS CLAVE: Energía de activación; Enzimas lipasa; Estabilidad oxidativa; Parámetros cinéticos

Citation/Cómo citar este artículo: Erim Köse Y. 2021. Kinetic modeling of oxidation parameters and activities of lipase-lipoxygenase in wheat germ oil. Grasas Aceites 72 (3), e423. https://doi.org/10.3989/gya.0554201

Copyright: (C2021 CSIC. This is an open-access article distributed under the terms of the Creative Commons Attribution 4.0 International (CC BY 4.0) License. 


\section{INTRODUCTION}

Wheat germ is the most valuable part of wheat with important nutritional components, such as essential amino acids (lysine, methionine, threonine), vitamins $\mathrm{E}$ and $\mathrm{B}$, dietary fiber, sugars, minerals and fat (Ali et al., 2013; Zhu et al., 2010). Germ also contains valuable antioxidant components such as phenolic acids, flavonoids and carotenoids, especially tocopherols, which have protective effects against free radicals. Wheat germ oil is the richest source of $\alpha$-tocopherol and is more unsaturated than other cereal oils. The highly unsaturated fatty acids and the activity of hydrolytic and oxidative enzymes (LA and LOX) in raw wheat germ are factors that accelerate the development of rancidity. LA is the primary enzyme that is responsible for the hydrolysis of triglycerides into glycerol and free fatty acids. LOX and peroxidase also play key roles in the deterioration of raw germ (Orthoefer, 2005). As a result, rancid-flavor, bitterness taste, and off-odor develop and finally, raw germ becomes completely inedible. Therefore, raw germ is mostly blended with wheat bran in the milling process and generally used as an animal feed all over the world (Ge et al., 2000). Several stabilization techniques have been used for inactivating LA activity, preventing rancidity and so improving the shelf-life of germ. Recently, the most popular stabilization method is a heat treatment which includes baking (Megahed, 2011; Attia and Abou-Gharbia, 2011; Meriles et al., 2019), roasting (Krings et al., 2000; Zou et al., 2018), toasting (Ali et al., 2013), MW drying (Srivastava et al., 2007; Zhang et al., 2008, Xu et al., 2013, Xu et al., 2016), drying in a fluidized bed dryer (Marti et al., 2014, Yöndem-Makascığlu et al., 2005), infrared drying (Jha et al., 2013; Li et al., 2016, Gili et al., 2017), extrusion cooking (Gomez et al., 2012), and moist heat treatment (Sudha et al., 2007; Srivastava et al., 2007).

Among these methods, MW treatment has a minimum effect on the nutrient loss from germ and also decreases the Maillard reaction rate because of its mechanism. Moreover, it provides rapid and uniform heating. Reports on wheat germ stabilization by MW generally deal with nutritional changes after stabilization. For example, Sjöwall et al. (2000) stabilized raw wheat germ by MW oven at $45-55^{\circ} \mathrm{C}$ and stored it for seven weeks at room temperature. Rancid odor and flavor changes were observed in the untreated wheat germ after three weeks, whereas no difference was observed in the MW-heated wheat germ after seven weeks of storage. A study by Zhang et al. (2008) revealed that MW could effectively destroy LOX enzyme in raw germ and improve shelf-life quality as well. Xu et al. (2016) measured LA and LOX activities as a result of the stabilization of raw germ in MW and convection ovens. These treatments inactivated enzymes completely with increasing temperature and time. Their study also showed that LA was more heat-stable than LOX. Xu et al. (2013) reported that there was a significant decrease in LA activity, and LOX became completely inactive in MW-treatment germ samples. In addition, it was reported that an increase in acidity was not high at the end of 60 days in the stabilized germs, which were subjected to a rapid oxidation test, and MW treatment could cause the death of harmful microorganisms. Previous studies have demonstrated that different stabilization and storage conditions of wheat germ have changed the physical, chemical or microbiological parameters of the germ drastically. Kinetic modeling is a good way to predict these changes in quality parameters during stabilization and also long-term storage conditions. Therefore, this study aimed to investigate the oxidation aspect parameters of raw germ during the stabilization of MW treatment and different storage conditions. In this study, valuable results were achieved regarding processing quality thanks to the calculated kinetic parameters.

\section{MATERIALS AND METHODS}

\subsection{Materials}

The raw wheat germ used in this study was obtained from the Sağlik Flour Company in Konya, Turkey. The samples were collected directly after milling in polyethylene bags and stored at a temperature of $-36{ }^{\circ} \mathrm{C}$ in a freezer until they were used. All chemicals were of analytical-reagent grade (Sigma-Aldrich, Oakville, Canada).

\subsection{Stabilization method and oil extraction}

Two hundred grams per batch of raw sample were heated in a MW oven (Arçelik, MD554) at $700 \mathrm{~W}$ for three min. The samples were spread out evenly to a thickness of $0.4 \mathrm{~cm}$ and heated at $100 \%$ power. The inner temperature of the sample was about $120 \pm 5^{\circ} \mathrm{C}$ 
after heating. The stabilized samples were kept at -18 , $0,+4$ and, $+25^{\circ} \mathrm{C}$ for 105 days in polyethylene bags after cooling to room temperature.

The oils of the germ samples were extracted using the cold extraction method. Wheat germ and hexane (10-fold hexane of wheat germ oil content) were homogenized with a homogenizer (Heidolph, Germany) for $90 \mathrm{~s}$ at $12500 \mathrm{rpm}$. The mixture was placed in the glass flask and shaken with a circular shaker for two hours at $200 \mathrm{rpm}$ and then filtered to the extraction flask. The above procedure was repeated twice and pooled filtrates were removed by a rotary vacuum evaporator at $40{ }^{\circ} \mathrm{C}$ at $150 \mathrm{rpm}$ (Heidolph, Germany) (Bakkalbaşı et al., 2012).

The wheat germ oil was extracted from stabilized and stored germ samples on days $0,15,30,45,60$, 75, 90, and 105. FFA, PV, TBA, and $\alpha$-tocopherol in germ oil samples were analyzed. LA and LOX activities were measured.

\subsubsection{Determination of oxidation parameters and enzyme activities}

The oxidative parameters of raw and stabilized germ oil samples were evaluated by the measurement of FFA, PV (AOCS 1994), TBA (Tarladgis et al., 1960), $\alpha$-tocopherol (AOCS 1994) and calculated LA (Xu et al., 2013) and LOX (Xu et al., 2016) activities.

\subsubsection{Kinetic modeling}

Zero-order (Eq. 1), first-order (Eq. 2) and secondorder (Eq. 3) kinetic models were used to describe the oxidation aspects and enzyme activity changes during storage with different storage temperatures of the MW-stabilized germ oil samples.

$$
\begin{aligned}
& C=C_{0} \pm k t \\
& C=C_{0} \exp ( \pm k t) \\
& 1 / \mathrm{C}=1 / \mathrm{C}_{0} \pm k t
\end{aligned}
$$

In these equations, $\mathrm{C}$ is quality parameter, $\mathrm{C}_{0}$ is the value of this quality parameter at its initial state, $\mathrm{t}$ is storage time (day) and $\mathrm{k}$ is kinetic constant (day-1). Where $(+)$ and $(-)$ indicated formation and degradation of the quality parameters, respectively.

\section{RESULTS AND DISCUSSION}

The oxidation parameters and activity of LA and LOX values of wheat germ oils extracted
TABLE 1. Parameters of raw and microwave-treated germ samples at the beginning of the storage

\begin{tabular}{lcc}
\hline Parameters & $\begin{array}{c}\text { Raw } \\
\text { Mean } \pm \text { SD }\end{array}$ & $\begin{array}{c}\text { Microwave-treated } \\
\text { Mean } \pm \text { SD }\end{array}$ \\
\hline FFA (\%) & $4.65 \pm 0.07$ & $2.44 \pm 0.17$ \\
Peroxide $\left(\mathrm{meqO}_{2} / \mathrm{kg}\right)$ & $3.60 \pm 0.22$ & $1.66 \pm 0.20$ \\
TBA $(\mathrm{mg} \mathrm{MA} / \mathrm{kg})$ & $0.278 \pm 0.02$ & $0.187 \pm 0.02$ \\
$\alpha$-tocopherols $(\mathrm{mg} / \mathrm{kg})$ & $1750 \pm 1.41$ & $1676 \pm 1.21$ \\
Lipase $(\mathrm{U} / \mathrm{g})$ & $4.77 \pm 0.04$ & $0.32 \pm 0.09$ \\
Lipoxygenase $(\mathrm{U} / \mathrm{mg})$ & $4.020 \pm 0.04$ & $\mathrm{nd}$ \\
\hline
\end{tabular}

Data are expressed as mean $\pm \mathrm{SD}$ (standard deviation) $(\mathrm{n}=3)$.

FFA: Free fatty acids, TBA: thiobarbituric acid, nd: not detected.

from raw, as well as MW-treated samples at the beginning of storage are given in Table 1. As the microwaves penetrate into the raw germ and target water molecules (Wray and Ramaswamy, 2015), the water activity decreases rapidly and reduces the rate of oxidative reactions by limiting both LA and LOX activities (Xu et al., 2013). Therefore, significant decreases $(\mathrm{p}<0.05)$ were observed in the primary and secondary oxidation products of the germ oils after exposure to MW heating. The FFA and PV of raw germ oil decreased from 4.65 to $2.44 \%$ oleic acid and 3.60 to $1.66 \mathrm{meqO} / \mathrm{kg}$ after stabilization using MW treatment, respectively. These results are comparable to previous stabilization studies conducted by Attia and Abou-Gharbia, 2011, Suresh Kumar et al., 2014 and Zou et al., 2018. However, Yöndem-Makascioğlu et al., 2005 and $\mathrm{Xu}$ et al., 2013 reported an increase in FFA and PV in MW-treated germ samples. In these studies, the water, which is the essential reactant for hydrolysis reaction may not be reduced due to an inadequate heat and time combination of the MW oven. Therefore, the hydrolysis reaction rate may not be decreased in these studies. The secondary products from the lipid oxidation of unsaturated fatty acids are generally measured by TBA value and stated as $\mathrm{mg}$ malondialdehyde/ $\mathrm{kg}(\mathrm{mgMA} / \mathrm{kg}$ ) (Sorensen and Jorgensen, 1996; Ercoşkun and Özkal, 2011). Its value decreased from 0.278 to $0.187 \mathrm{mg} \mathrm{MA} /$ $\mathrm{kg}$ product during MW treatment. The LA of raw germ oil was $4.77 \mathrm{U} / \mathrm{g}$, while the MW-treated germ remained at $0.32 \mathrm{U} / \mathrm{g}$. All of the MW-treated samples (stored with different conditions for 105 days) retained some residual LA activity. However, MW-treated samples lost LOX activity completely 
TABLE 2. Kinetic parameters of microwave-treated germ samples after 105 days of storage.

\begin{tabular}{|c|c|c|c|c|c|c|}
\hline Parameter & Storage Temperature & Model & $\begin{array}{c}\mathrm{C}_{0} \\
\text { Mean } \pm \mathrm{SD}\end{array}$ & $\begin{array}{c}\mathbf{k}\left(\text { day }^{-1}\right) \\
\text { Mean } \pm \text { SD }\end{array}$ & $\mathbf{R}^{2}$ & $E_{a}(\mathrm{kj} / \mathrm{mol})$ \\
\hline \multirow{4}{*}{ FFA } & $-18^{\circ} \mathrm{C}$ & \multirow{4}{*}{ First-order kinetic } & $2.408 \pm 1.42$ & $0.0110 \pm 0.22$ & 0.988 & \multirow{4}{*}{6.98} \\
\hline & $0^{\circ} \mathrm{C}$ & & $2.519 \pm 0.97$ & $0.0134 \pm 0.66$ & 0.995 & \\
\hline & $4{ }^{\circ} \mathrm{C}$ & & $2.593 \pm 1.07$ & $0.0156 \pm 0.34$ & 0.993 & \\
\hline & $25^{\circ} \mathrm{C}$ & & $2.785 \pm 1.02$ & $0.0175 \pm 0.22$ & 0.994 & \\
\hline \multirow{4}{*}{ PV } & $-18^{\circ} \mathrm{C}$ & \multirow{4}{*}{ Zero-order kinetic } & $0.828 \pm 0.65$ & $0.0999 \pm 0.25$ & 0.972 & \multirow{4}{*}{5.95} \\
\hline & $0^{\circ} \mathrm{C}$ & & $1.457 \pm 1.12$ & $0.1080 \pm 0.84$ & 0.994 & \\
\hline & $4{ }^{\circ} \mathrm{C}$ & & $1.569 \pm 1.27$ & $0.1275 \pm 0.13$ & 0.991 & \\
\hline & $25^{\circ} \mathrm{C}$ & & $1.582 \pm 1.03$ & $0.1483 \pm 0.21$ & 0.961 & \\
\hline \multirow{4}{*}{ TBA } & $-18^{\circ} \mathrm{C}$ & \multirow{4}{*}{ Second-order kinetic } & $0.197 \pm 0.19$ & $-0.0095 \pm 0.04$ & 0.718 & \multirow{4}{*}{6.54} \\
\hline & $0{ }^{\circ} \mathrm{C}$ & & $0.193 \pm 0.58$ & $-0.0113 \pm 0.05$ & 0.611 & \\
\hline & $4{ }^{\circ} \mathrm{C}$ & & $0.205 \pm 0.30$ & $-0.0138 \pm 0.04$ & 0.789 & \\
\hline & $25^{\circ} \mathrm{C}$ & & $0.220 \pm 0.66$ & $-0.0146 \pm 0.02$ & 0.742 & \\
\hline \multirow{4}{*}{$\alpha$-tocopherol } & $-18^{\circ} \mathrm{C}$ & \multirow{4}{*}{ First-order kinetic } & $1667.532 \pm 2.82$ & $-0.0004 \pm 0.00$ & 0.925 & \multirow{4}{*}{18.5} \\
\hline & $0{ }^{\circ} \mathrm{C}$ & & $1680.253 \pm 2.12$ & $-0.001 \pm 0.00$ & 0.967 & \\
\hline & $4^{\circ} \mathrm{C}$ & & $1679.580 \pm 2.44$ & $-0.0012 \pm 0.01$ & 0.997 & \\
\hline & $25^{\circ} \mathrm{C}$ & & $1656.065 \pm 2.21$ & $-0.0014 \pm 0.01$ & 0.927 & \\
\hline \multirow{4}{*}{ LA } & $-18^{\circ} \mathrm{C}$ & \multirow{4}{*}{ Zero-order kinetic } & $0.0133 \pm 0.24$ & $0.0349 \pm 0.00$ & 0.976 & \multirow{4}{*}{5.72} \\
\hline & $0^{\circ} \mathrm{C}$ & & $0.2783 \pm 0.41$ & $0.0365 \pm 0.08$ & 0.988 & \\
\hline & $4{ }^{\circ} \mathrm{C}$ & & $0.3900 \pm 0.38$ & $0.039 \pm 0.02$ & 0.993 & \\
\hline & $25^{\circ} \mathrm{C}$ & & $0.477 \pm 1.05$ & $0.0514 \pm 0.08$ & 0.972 & \\
\hline LOX & nd & & & & & \\
\hline
\end{tabular}

Data are expressed as mean \pm SD (standard deviation $)(n=3)$. FFA: Free fatty acids, PV: peroxide value, TBA: thiobarbituric acid, LA: lipase activity, LOX: lipoxygenase activity, nd: not detected.

(Table 1). From this research, it was evident that LA is tolerable to heat in low moisture systems like MW-oven, and also LOX is more thermally sensitive under the same conditions of LA. This phenomenon is supported by previous studies on heat-stabilized wheat germ (Sudha et al., 2007; Attia and AbouGharbia, 2011, Xu et al., 2013; Li et al., 2016). The content in vitamin E ( $\alpha$-tocopherol) changed drastically in MW-treated wheat germ compared to raw samples because of the low thermal stability of $\alpha$-tocopherol (Srivastava et al., 2007; Y1lmaz et al., 2014).

Table 2 shows the estimated kinetic parameters of oxidation and enzyme activity values for wheat germ oils which were extracted from MW-treated samples under different storage conditions. The high determination coefficient of $\mathrm{R}^{2}$ value was confirmed as the most accurate fit. Only the models with the highest $\mathrm{R}^{2}$ values are presented in Table 2 . The reaction rate constant $(\mathrm{k})$ and the initial quality value $\left(\mathrm{C}_{0}\right)$ were also calculated for all the oxidation quality parameters.

Changes in FFA during the storage of MW-treated germ samples with different storage temperatures are given in Figure 1. As expected, the amounts of FFA increased with increasing storage temperature and time. It was best represented by the first-order kinetic model with high $\mathrm{R}^{2}$ (0.994-0.988). The highest FFA value $(16.32 \%)$ was observed in the sample, which was stored at $25{ }^{\circ} \mathrm{C}$ on day 105 . Hydrolytic and oxidative rancidity in wheat germ oil during longterm storage is responsible for this increase. Similar results were found for wheat germ oil by (Attia and Abou-Gharbia, 2011; Megahed, 2011; Mahmoud 
et al., 2015). Generally, the first products of lipid oxidation appear within a certain storage period in foods and as can be seen in Figure 2, the PV increased during long-term storage. The initial and

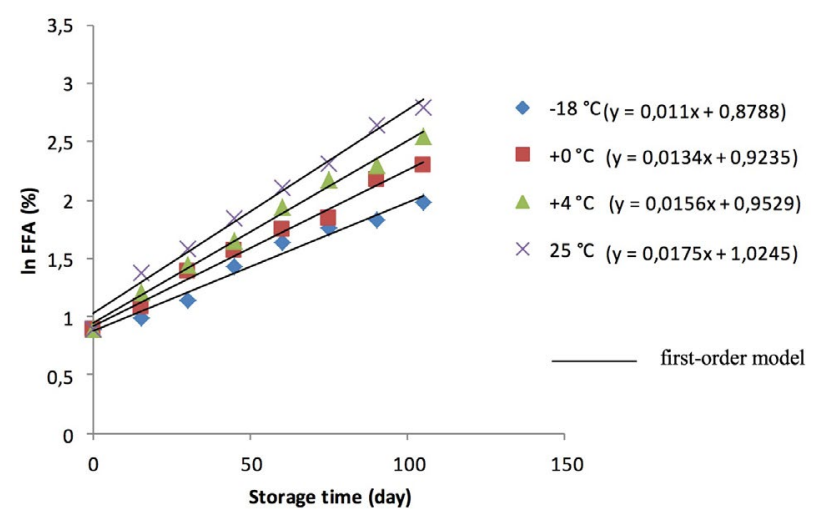

FIGURE 1 . Kinetic changes in the free fatty acids (FFA) of the MW-stabilized wheat germ oil during storage. Three replicates were performed for each kinetic experiment $(n=3)$.

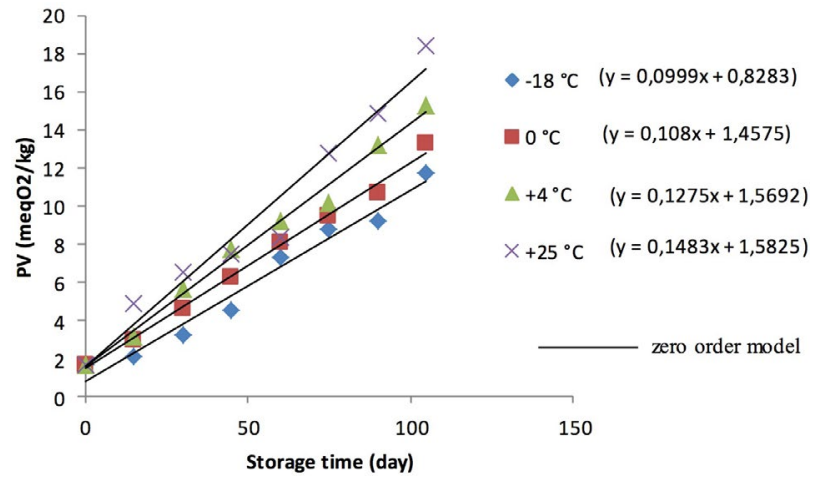

FIGURE 2. Kinetic changes in the peroxide value (PV) of the MW-stabilized wheat germ oil during storage. Three replicates were performed for each kinetic experiment $(n=3)$.

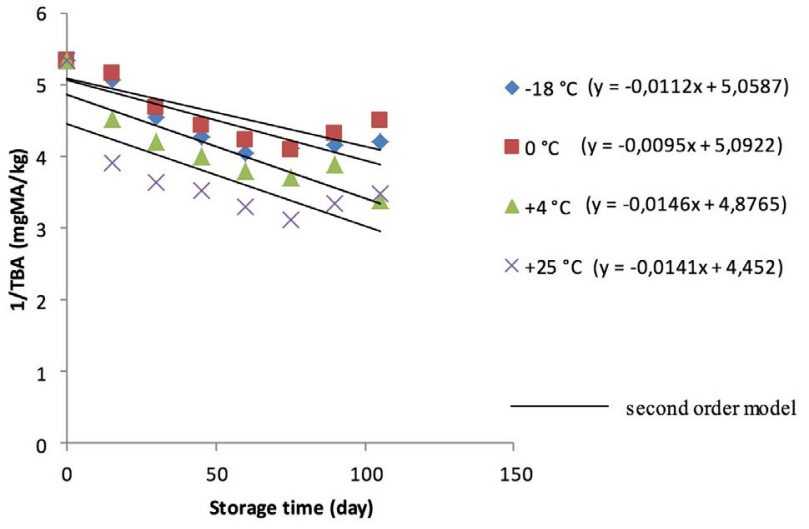

FigURE 3. Kinetic changes in the thiobarbituric acid (TBA) of the MW-stabilized wheat germ oil during storage. Three replicates were performed for each kinetic experiment $(n=3)$. final PV increased from 1.66 to 11.76 and 18.44 meq $\mathrm{O}_{2} / \mathrm{kg}$. This increase may be due to the hydrolytic rancidity of germ oil by residual LA activity. (As was previously reported, the enzyme inactivation process is not enough in a MW-oven because of the thermal-stability of LA). The results obtained were in agreement with the studies published in the literature that the PV of germ oil was increased under long-term storage conditions (Hygreeva, 2013; Li et al., 2016; Zou et al., 2018). For the mathematical modeling of PV, a zero-order kinetic model was used (Figure 2). The kinetic rate constant $(\mathrm{k})$ of FFA and PV increased from 0.011 to 0.0175 and 0.0999 to 0.1483 day $^{-1}$, respectively. This suggests that the degradation rate of primary products of lipid oxidation becomes faster as a result of high storage

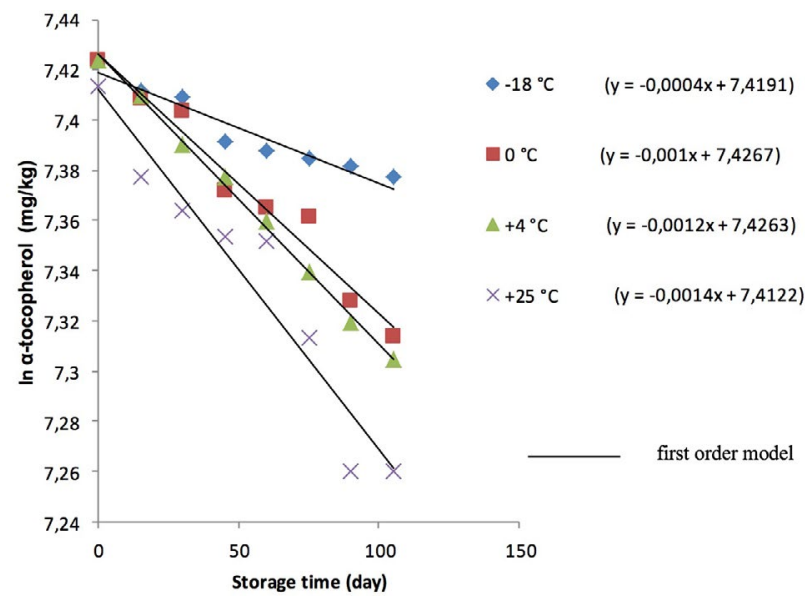

FigURE 4. Kinetic changes in the $\alpha$-tocopherol of the MW-stabilized wheat germ oil during storage. Three replicates were performed for each kinetic experiment $(\mathrm{n}=3)$.

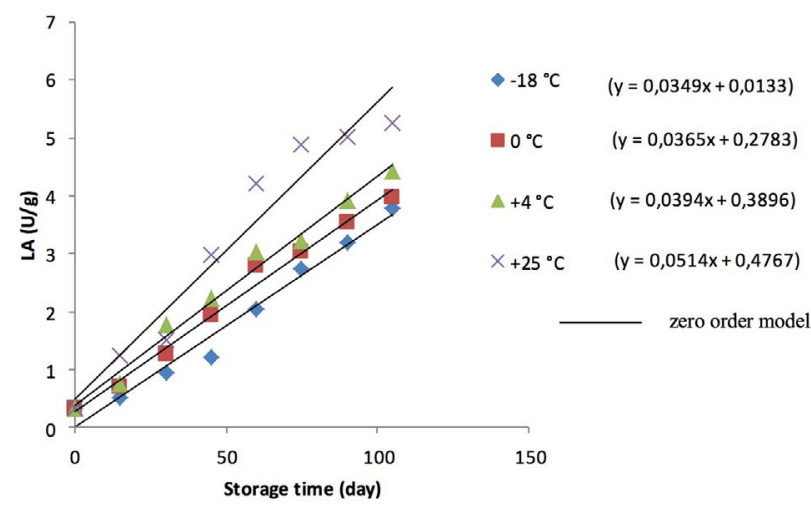

FIGURE 5. Kinetic changes in the lipase activity (LA) of the MW-stabilized wheat germ oil during storage. Three replicates were performed for each kinetic experiment $(n=3)$. 
temperature. A linear increase was observed in the TBA values of all samples in the first 60 days of storage, but a small decrease was determined from day 75. The increase in TBA indicates the formation of secondary products due to more intense lipid oxidation in the first 60 days, while the decrease in TBA may be indicative of the degradation of these components to volatile compounds at later stages of storage (Ercoşkun and Özkal, 2011). At the end of the storage period, the highest value for TBA $(0.333$ $\mathrm{mg} \mathrm{MA} / \mathrm{kg}$ ) was determined in the sample stored at $25{ }^{\circ} \mathrm{C}$ on day 60 . Changes in TBA value were best represented by the second-order kinetic model with negative $\mathrm{k}$ values being changed from -0.0095 to -0.0146 (Figure 3). The $\alpha$-tocopherol content decreased during the storage period (Figure 4). Although this decrease was fast in the samples stored at $25^{\circ} \mathrm{C}$, it was slow at lower temperatures. It was also observed that increased storage time accelerated a loss in tocopherol. The change in $\alpha$-tocopherol content was determined by Capitani et al. (2011), and was dependent on the storage conditions of the germ. The reported values were in agreement with the data in this study. a $35 \%$ reduction has been reported in the $\alpha$-tocopherol content in the germ with increasing storage time and storage temperature. The decrease in $\alpha$-tocopherol content was best represented by the first-order kinetic model with the negative $\mathrm{k}$-value changing from -0.0004 to -0.0014 (Table 2). Figure 5 shows that a linear increase was determined for the LA activity value, and this enzyme process can be described by the zero-order kinetic model. On the other hand, LOX activity completely disappeared immediately after MW treatment, so no modeling was done. As mentioned above, under the same conditions, LA is more tolerable to heat than LOX.

The Arrhenius model described the temperature dependence of the reaction rate constant for all the oxidation parameters, and the estimated activation energies, which had the highest $\mathrm{R}^{2}$ values are also shown in Table 2.

Arrhenius relationship:

$$
\ln k=\ln A-\left(\frac{\mathrm{E}_{\mathrm{a}}}{R t}\right)
$$

where $\mathrm{k}$ is the reaction rate constant; $\mathrm{A}-$ preexponential factor; Ea is the activation energy $(\mathrm{kJ} /$ mol); $\mathrm{R}$ is the universal gas constant $(\mathrm{kJ} / \mathrm{molK})$, and $\mathrm{T}$ is the absolute temperature $(\mathrm{K})$.

\section{CONCLUSIONS}

Many studies on the stabilization of raw wheat germ have focused on traditional heating methods. Recently, MW treatment has been widely used to prevent wheat germ from oxidation with inactivation of enzymes and minimum effects on the nutritional value. In this study, a MW-stabilization technique for wheat germ and wheat germ oil was investigated using experimental and analytical methods for quality parameters of the oxidation. Findings in the kinetic evaluation of MW conditions showed that the acid value of raw wheat germ oil decreased by $47.5 \%$ after MW treatment. The same trend was observed for other oxidation parameters. As expected, decreasing the storage temperature slowed down the oxidation rate and ideal storage temperature was $-18{ }^{\circ} \mathrm{C}$ in all samples. MW treatment inactivated LOX completely, while LA was reduced to $93.2 \%$ and the zero-order kinetic equation fit the LA inactivation curve quite well. These results reveal that LOX is more thermally sensitive under the same conditions of LA. The kinetic models used in this study adequately described the MW process and gave oxidation values that were in good agreement with the experimental results. For the process, the activation energy was also calculated, assuming an Arrhenius-type temperature reliance. Thanks to this study, the effects of different stabilization methods on the quality of different cereal wastes like germ can be investigated following the same parameters and models.

\section{REFERENCES}

Ali S, Usman S, Nasreen Z, Zahra N, Nazir S, Yasmeen A, Yaseen T. 2013. Nutritional evaluation and stabilization studies of wheat germ. Pak. J. Food Sci. 23, 148-152.

AOCS 1994. Official Methods and Recommended Practices of the American Oil Chemists'Society, 4th Edition. AOCS Press, Illinois.

Attia RS, Abou-Gharbia HA. 2011. Evaluation and stabilization of wheat germ and its oil characteristics. Alex J. Fd. Sci. Technol. 8, 31-39.

Bakkalbaşı E, Yılmaz ÖM, Javidipour I, Artık N. 2012. Effects of packaging materials, storage conditions and variety on oxidative stability of shelled walnuts. LWT-Food Sci Technol. 46, 203209. https://doi.org/10.1016/j.lwt.2011.10.006 
Capitani M, Mateo CM, Nolasco SM. 2011. Effect of temperature and storage time of wheat germ on the oil tocopherol concentration. Braz. J. Chem. Eng. 28, 243-250. https://doi.org/10.1590/S010466322011000200008

Ercoşkun H, Özkal SG. 2011. Kinetics of traditional Turkish sausage quality aspects during fermentation. Food Control 22 (2), 165-172. https://doi.org/10.1016/j.foodcont.2010.06.015

Ge Y, Sun A, Ni Y, Cai T. 2000. Some nutritional and functional properties of defatted wheat germ protein. J. Agric. Food. Chem. 48, 6215-6218. https://doi.org/10.1021/jf000478m

Gili RD, Palavecino PM, Penci MC, Martinez ML, Ribotta PD. 2017. Wheat germ stabilization by infrared radiation. J. Food Sci. Technol. 54, 7181. DOI:10.1007/s13197-016-2437-z

Gomez M, Gonzalez J, Oliete B. 2012. Effect of extruded wheat germ on dough rheology and bread quality. Food Bioprocess Technol. 5, 2409-2418. https://doi.org/ 10.1007/s11947-011-0519-5.

Hygreeva D, Pandey MC, Radhakrishna K. 2012. A preliminary study on evaluation of antioxidant activity and oxidatıve stability of wheat germ oil in poultry and mutton meat systems. IJFANS 2, 40-46.

Jha PK, Kudachikar VB, Kumar S. 2013. Lipase inactivation in wheat germ by gamma irradiation. Radiat. Phys. Chem. 86, 136-139. https://doi.org/ 10.1016/j.radphyschem.2013.01.018

Krings U, El-Saharty YS, El-Zeany BA, Pabel B, Berger RG. 2000. Antioxidant activity of extracts from roasted wheat germ. Food Chem. 71, 91-95. https://doi.org/ 10.1016/S0308-8146(00)00148-5

Li B, Zhao L, Chen H, Sun D, Deng B, Li J, Liu Y, Wang F. 2016. Inactivation of lipase and lipoxygenase of wheat germ with temperaturecontrolled short wave infrared radiation and its effect on storage stability and quality of wheat germ oil. Plos One 11, 1-13. https://doi. org/10.1371/journal.pone.0167330

Marti A, Torri L, Casiraghi MC, Franzetti L, Limbo S, Morandin F, Pagani MA. 2014. Wheat germ stabilization by heat-treatment or sourdough fermentation: Effects on dough rheology and bread properties. LWT-Food Sci. Technol. 59, 11001106. https://doi.org/10.1016/j.lwt.2014.06.039

Mahmoud AA, Mohdaly AA, Elneairy NA. 2015. Wheat germ: an overview on nutritional value, antioxidant potential and antibacterial characteristics. Food Nutr. Sci. 6, 265-277. https://doi.org/10.4236/fns.2015.62027

Megahed MG. 2011. Study on stability of wheat germ oil and lipase activity of wheat germ during periodical storage. Agric. Biol.J. N.Am. 2, 163-168. https://doi.org/10.5251/abjna.2011.2.1.163.168

Meriles SP, Steffolani ME, León AE, Penci MC, Ribotta PD. 2019. Physico-chemical characterization of protein fraction from stabilized wheat germ. Food Sci. Biotechnol. 28, 1327-1335. https://doi. org/10.1007/s10068-019-00594-9

Orthoefer FT. 2005. Rice bran oil. Bailey's industrial oil and fat products. https://doi. org/10.1002/047167849X.bio015

Sjövall O, Virtalaine T, Lapveteläinen A, Kallio H. 2000. Development of rancidity in wheat germ analyzed by headspace gas chromatography and sensory analysis. J. Agric. Food Chem. 48, 35223527. https://doi.org/10.1021/jf981309t

Sudha ML, Srivastava AK, Leelavathi K. 2007. Studies on pasting and structural characteristics of thermally treated wheat germ. Eur. Food Res. Technol. 225, 351-357. https://doi.org/10.1007/ s00217-006-0422-x

Srivastava AK, Sudha ML, Baskaran V, Leelavathi K. 2007. Studies on heat stabilized wheat germ and its influence on rheological characteristics of dough. Eur. Food Res. Technol. 224, 365-372. https://doi.org/10.1007/s00217-006-0317-x

Suresh Kumar G, Swathi R, Gopala Krishna AG. 2014. Fat-soluble nutraceuticals and their composition in heat-processed wheat germ and wheat bran. Int. J. Food Sci. Nutr. 65, 327-334. https://doi.org/10.3109/09637486.2013.866640

Sørensen G, Jørgensen SS. 1996. A critical examination of some experimental variables in the 2-thiobarbituric acid (TBA) test for lipid oxidation in meat products. Z. Lebensm. Unters Forsch. 202, 205-210. https://doi.org/10.1007/BF01263541

Tarladgis BG, Watts BM, Younathan MT, Dugan L. 1960. A distillation method for the quantitative determination of malonaldehyde in rancid foods. J. Am. Oil Chem. Soc. 37 44-48. https://doi. org/10.1007/BF02630824

Xu B, Zhou SL, Miao WJ, Gao C, Cai MJ, Dong Y. 2013. Study on the stabilization effect of continuous microwave on wheat germ. $J$. Food Eng. 117, 1-7. https://doi.org/ 10.1016/j. jfoodeng.2013.01.031 
Xu B, Wang LK, Miao WJ, Wu QF, Liu YX, Sun Y, Gao C. 2016. Thermal versus microwave inactivation kinetics of lipase and lipoxygenase from wheat germ. J. Food Process Eng. 39, $247-$ 255. https://doi.org/ 10.1111/jfpe. 12216

Yöndem-Makascioğlu F, Gürün B, Dik T, Suzan Kincal N. 2005. Use of a spouted bed to improve the storage stability of wheat germ followed in paper and polyethlyene packages. J. Sci. Food Agric. 85, 1329-1336. https://doi.org/ 10.1002/ jsfa. 2102

Wray Derek, Ramaswamy HS. 2015. Novel concepts in microwave drying of foods. Drying Technol. 33 (7), 769-783. https://doi.org/10.1080/07373937.2 014.985793

Y1lmaz N, Tuncel NB, Kocabiy1k H. 2014. Infrared stabilization of rice bran and its effects on $\gamma$-oryzanol content, tocopherols and fatty acid composition. J. Sci. Food Agric. 94, 1568-1576. https://doi.org/10.1002/jsfa.6459

Zhu KX, Sun XH, Chen ZC, Peng W, Qian HF, Zhou HM. 2010. Comparison of functional properties and secondary structures of defatted wheat germ proteins separated by reverse micelles and alkaline extraction and isoelectric precipitation. Food Chem. 123, 1163-1169. https://doi.org/ 10.1016/j.foodchem.2010.05.081

Zou Y, Gao Y, He H, Yang T. 2018. Effect of roasting on physico-chemical properties, antioxidant capacity, and oxidative stability of wheat germ oil. LWT-Food Sci. Technol. 90, 246-253. https:// doi.org/10.1016/j.lwt.2017.12.038

Zhang YR, Zhou XQ, Guo Y R. 2008. Study on the technological parameters of de actıvatıng enzyme in wheat germ by microwave. Journal of Henan University of Technol. (Natural Sci. Edt.) 2, 7-10. 